\title{
Optimization of bacteriocin production by Lactobacillus sp. MSU3IR against shrimp bacterial pathogens
}

\author{
Palanisamy lyapparaj ${ }^{1 *}$, Thirumalai Maruthiah ${ }^{2}$, Ramasamy Ramasubburayan ${ }^{2}$, Santhiyagu Prakash $^{3}$, \\ Chandrasekaran Kumar ${ }^{4}$, Grasian Immanuel ${ }^{2}$ and Arunachalam Palavesam²
}

\begin{abstract}
Background: Aquaculture is one amongst the growing and major food producing sectors. Shrimp culture is one of the subsectors of aquaculture that attracts more attention because of the economic interest. However, the shrimp culture systems have been facing severe consequences and economical losses due to disease outbreaks. Risk of disease outbreak can be combated with the application of probiotics. For economically viable production of such probiotic products, the present study provides information on the optimization and partial purification of bacteriocin produced by a goat milk isolate Lactobacillus sp. MSU3IR against the shrimp bacterial pathogens.

Results: Bacteriocin production was estimated as a measure of bactericidal activity (arbitrary Unit/ml) over the test strains. The optimum culture conditions and media components for maximum bacteriocin production by Lactobacillus sp. MSU3IR were: $\mathrm{pH}$ : 5.0, temperature: $30^{\circ} \mathrm{C}$, carbon source: lactose; nitrogen source: ammonium acetate; $\mathrm{NaCl}: 3.0 \%$ and surfactant: Tween 80. MRS medium was found to extend better bacteriocin production than other tested media. Upon partial purification of bacteriocin, the SDS-PAGE analysis had manifested the presence of two peptide bands with the molecular weight of 39.26 and $6.38 \mathrm{kDa}$, respectively.

Conclusion: The present results provide baseline trend for the statistical optimization, scale up process and efficient production of bacteriocin by the candidate bacterial strain Lactobacillus sp. MSU3IR which could be used to replace the usage of conventional chemotherapeutics in shrimp culture systems.
\end{abstract}

Keywords: Aquaculture, Bacteriocin, Lactobacillus, Probiotics, Shrimp pathogens

\section{Background}

Aquaculture has become a popular food producing sub sector complement to agriculture. Diseases caused by bacteria and viruses are considered to be an important problem in the intensive rearing of molluscs, finfish, lobster and shrimp [1]. During disease outbreaks, mortality can be as high as $100 \%$ [2-5]. Infections caused by pathogenic strains belonging to the species Aeromonas hydrophila, Vibrio harveyi, V. parahaemolyticus, V.cholerae and $V$. anguillarium cause traumatic losses in the culture of molluscs, fish and shrimp [2,6-9]. Antibiotics have been widely used to control this problem. In recent years, the

\footnotetext{
* Correspondence: bioiypps@yahoo.co.in

${ }^{1}$ CAS in Marine Biology, Faculty of Marine Sciences, Annamalai University, Parangipettai - 608 502, Tamilnadu, India

Full list of author information is available at the end of the article
}

therapeutic use of antibiotics against bacterial infection is very much restricted in aquaculture due to its residual effect and development of resistance in bacteria. Hence, the probiotics are extensively used for disease management in aquaculture.

The use of probiotics is prevalent in the aquaculture industry (particularly in shrimp culture) as a means of controlling disease, improving water quality by balancing nutrient (e.g., nitrogen and phosphorus) availability and replacing the use of antibiotics and disinfectants in some cases [10-13]. Probiotics are known to block pathogens by disrupting their virulent gene expression, attachment and cell to cell communication [14]. Probiotic bacteria can also compete with the pathogens for available space and nutrients at host surfaces [15,16]. Many probiotic strains produce antimicrobials, such as lytic enzymes, 
iron-chelating compounds, antibiotics, hydrogen peroxide, organic acids and bacteriocins $[17,18]$. Bacteriocins are small peptides that disrupt the integrity of bacterial cell membranes $[19,20]$. As an alternative tool to control pathogenic bacteria, antimicrobial peptides or bacteriocins are recently being considered. Lactic acid bacteria (LAB) are one of the major resources for bacteriocin biosynthesis.

$\mathrm{LAB}$ are comprised of at least ten genera according to taxonomic revisions representing Aerococcus, Carnobacterium, Enterococcus, Lactobacillus, Lactococcus, Leuconostoc, Pediococcus, Streptococcus, Tetragenococcus and Vasococcus [21]. They are widely used as starter cultures in a variety of food fermentations. It is well known that many lactic acid bacteria show antagonistic activities against other bacteria, including food spoilage organisms and food borne pathogens. There are several different mechanisms responsible for this inhibition. In most cases, the inhibition is caused by the production of organic acid, hydrogen peroxide and bacteriocins [22,23].

Several reports have shown that complex media and well controlled physical factors, such as temperature and $\mathrm{pH}$ are required to obtain optimal bacteriocin production [24-27]. Bacteriocin production can be influenced by medium composition and growth phase of microorganism [28]. The production of bacteriocins is usually studied on complex rich media and the most currently evaluated parameters are the concentration of the carbon source, complex nitrogen source and Tween 80 [29,30]. In the light of the above statements, lactic acid bacteria (probionts) and their products (bacteriocins) could be an eco-friendly antimicrobials for substituting the commercial and synthetic antibiotics in aquaculture. However, optimization of culture media for efficient production of bacteriocin that mitigate the growth of shrimp pathogens are under researched. Hence, the present attempt has been undertaken to investigate the influence of various culture conditions and media components on bacteriocin production by Lactobacillus sp. MSU3IR.

\section{Results and discussion}

Aquaculture operation alleviates protein shortage and supplies high quality animal to human beings. Also, an environmentally sound and sustainable extensive aquaculture provide employment opportunities and generates income for the people [1]. Shrimp culture scored the major part of the economy across the world. But one of the main obstacles in shrimp culture is disease prevalence. Use of probiotic bacteria to prevent or reduce the risk of diseases is receiving attention as an alternative to antibiotics $[11,31,32]$. Evaluation of probiotic bacteria capable of producing bacteriocin is becoming an area of rigorous research in several sectors of human nutrition, in animal husbandry and in fish farming [33]. In this context, the present investigation was undertaken to optimize the bacteriocin production by Lactobacillus sp. MSU3IR with varying culture conditions and media components for its further application in the field of aquaculture.

\section{Lactobacillus strains}

The Lactobacillus load of goat milk was ranged from $613.0 \pm 6.53$ to $96.3 \pm 5.73 \mathrm{CFU} / \mathrm{ml}$ in $10^{-3}$ to $10^{-5}$ dilution respectively [Table 1]. In total, five Lactobacillus strains were isolated on MRS agar plates.

\section{Screening of bacteriocin production}

The isolated Lactobacillus strains were screened for antagonistic activity against indicator strains by the double layer method. Amongst the five strains tested, the candidate bacterium had maximum bioactivity as indicated by the formation of large and clear zone around the colony. With respect to the growth curve, the bacteriocin production by the candidate bacterium was high at the end of stationary phase (48h; data not shown). A similar trend of maximum accumulation of bacteriocin during the stationary phase of growth of Carnobacterium piscicola isolated from marine salmonids Salmo salar was reported [34,35].

Results indicated that the bioactivity of cell free neutralized supernatant (CFNS) was lost during the treatment with proteinase $K$, $\alpha$-chymotrypsin and trypsin whereas catalase had not altered the antagonistic property of CFNS. Thus, it confirmed the presence of bacteriocin in CFNS of candidate bacterium. Accordingly, numerous investigators have shown that bacteriocin activity is lost upon treatment with pepsin, trypsin or $\alpha$ - chymo trypsin because of denaturation [22,33,36,37].

Furthermore, this potent bacterium was subjected to molecular characterization using $16 \mathrm{~S}$ rRNA sequencing. The phylogenetic position of candidate bacterium with BLAST analysis inferred 96\% similarity to Lactobacillus sp. Furthermore, the 16S rRNA sequence of candidate bacterium showed $53.1 \%$ GC content with 1371 bp in length and it has been deposited in GenBank [JN561696], NCBI, USA. Phylogenetic analysis revealed that, 16S rRNA sequence of the candidate bacterium has $100 \%$ similarity with the existing stain Lactobacillus casei AB605428 [Figure 1].

Table 1 Enumeration of Lactobacillus load (CFU/ml) in Indian goat milk

\begin{tabular}{lllll}
\hline Dilution factor & Plate $\mathbf{1}$ & Plate $\mathbf{2}$ & Plate $\mathbf{3}$ & Mean $\mathbf{\pm}$ SD \\
\hline $10^{-1}$ & TNTC & TNTC & TNTC & - \\
$10^{-2}$ & TNTC & TNTC & TNTC & - \\
$10^{-3}$ & 605 & 621 & 613 & $613.0+6.53$ \\
$10^{-4}$ & 311 & 281 & 290 & $294.0+12.56$ \\
$10^{-5}$ & 97 & 103 & 89 & $96.3+5.73$ \\
\hline
\end{tabular}




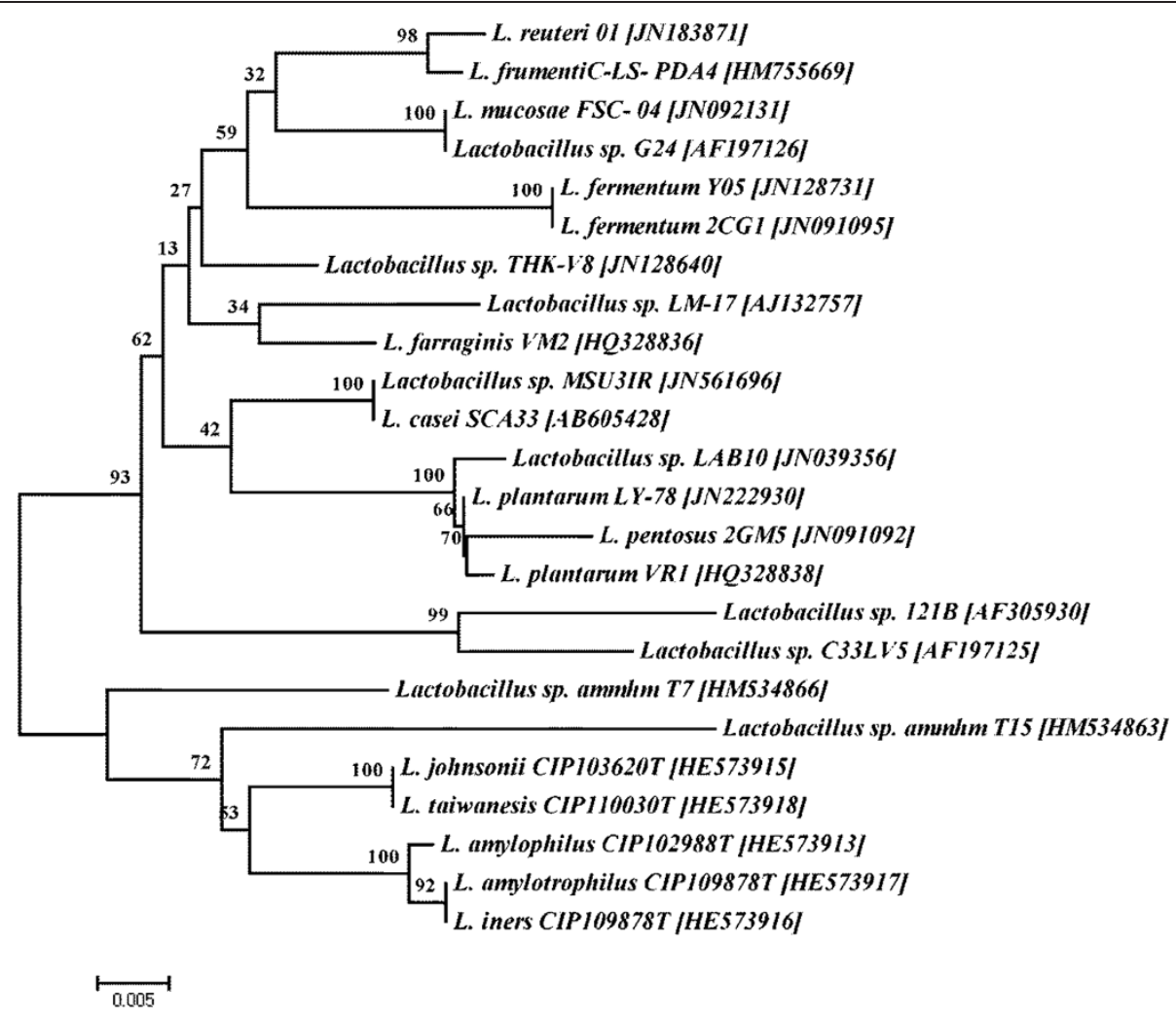

Figure 1 Phylogenetic tree of the candidate bacterium Lactobacillus sp. MSU3IR.

\section{Optimization of culture condition}

Subsequent study was carried out to optimize the bacteriocin production at the end of stationary phase $(48 \mathrm{~h})$ by Lactobacillus sp. MSU3IR and the bacteriocin production was measured in terms of antagonistic activity $(\mathrm{AU} / \mathrm{ml})$. The environmental factors, such as $\mathrm{pH}$ and temperature has to be optimized for maximum bacteriocin production. Likewise, the bacteriocin production was enhanced by culture conditions optimization in $L$. casei [38] and Leuconostoc mesenteroides [39].

Among the tested $\mathrm{pH}$, the maximum bacteriocin production in terms of antagonistic activity was recorded at $\mathrm{pH} 5.0$ and it ranged from $410.4 \pm 2.37$ to $649.2 \pm$ $5.18 \mathrm{AU} / \mathrm{ml}$. However, further increase in $\mathrm{pH}$ found to mitigate the bacteriocin production. The minimum bacteriocin production was recorded at $\mathrm{pH} 9.0$ and it ranged from $238.4 \pm 2.34$ to $390.4 \pm 4.16 \mathrm{AU} / \mathrm{ml}$ against the control range of $484.0 \pm 3.01$ to $604.0 \pm 5.63 \mathrm{AU} / \mathrm{ml}$ [Figure 2]. Two-way ANOVA revealed that bacteriocin production due to indicator strains is not statistically significant ( $\mathrm{F}: 1.224 ; \mathrm{P}>0.05)$ whereas it was statistically significant (F: 6.123; $\mathrm{P}<0.01$ ) for medium $\mathrm{pH}$. In consonance, the optimum $\mathrm{pH}$ for bacteriocin production was usually 5.5 to 6.0 [25,26,40-43]. Comparably the optimum $\mathrm{pH}$ for certain bacteriocin production was reported to be less than 5.0 [44-47].
Likewise, the higher bacteriocin production of $464.0 \pm$ 3.13 to $584.0 \pm 5.18 \mathrm{AU} / \mathrm{ml}$ was recorded at $30^{\circ} \mathrm{C}$ and further increase in temperature markedly decreased bacteriocin production and the minimum bacteriocin yield was within the range of $272.0 \pm 2.29$ to $90.4 \pm 3.49 \mathrm{AU} / \mathrm{ml}$ at $60^{\circ} \mathrm{C}$ over the control $(344.0 \pm 2.45$ to $473.2 \pm 5.47$ $\mathrm{AU} / \mathrm{ml}$ ) [Figure 3]. Statistical analysis with two-way ANOVA inferred that the bacteriocin yield was significant due to indicator strains $(\mathrm{F}: 1.188 ; \mathrm{P}<0.05)$ but it was significant (F: 5.479; $\mathrm{P}<0.01)$ for incubation temperature. Similarly, Moonchai et al. [48] also reported that the bacteriocin production by $L$. lactis was optimum at $30^{\circ} \mathrm{C}$.

\section{Optimization of media components}

Lactose supplementation in culture media favored the maximum bacteriocin yield by Lactobacillus sp. MSU3IR in terms of bioactivity ranged from $542.4 \pm 3.49$ to 685.2 $\pm 5.90 \mathrm{AU} / \mathrm{ml}$. However, the minimum antagonistic activity $(313.2 \pm 2.37$ to $417.2 \pm 3.92 \mathrm{AU} / \mathrm{ml})$ was recorded in mannitol supplied medium over the control value from $306.4 \pm 2.65$ to $381.2 \pm 5.18 \mathrm{AU} / \mathrm{ml}$ [Figure 4]. Variation in bacteriocin production due to indicator strains was not statistically significant (F: 0.593; P> 0.05) besides, it was significant ( $F: 18.504 ; \mathrm{P}<0.001$ ) for tested carbon sources. In line with our results, Moreno et al. [49] reported maximum bacteriocin yield by E. faecium 


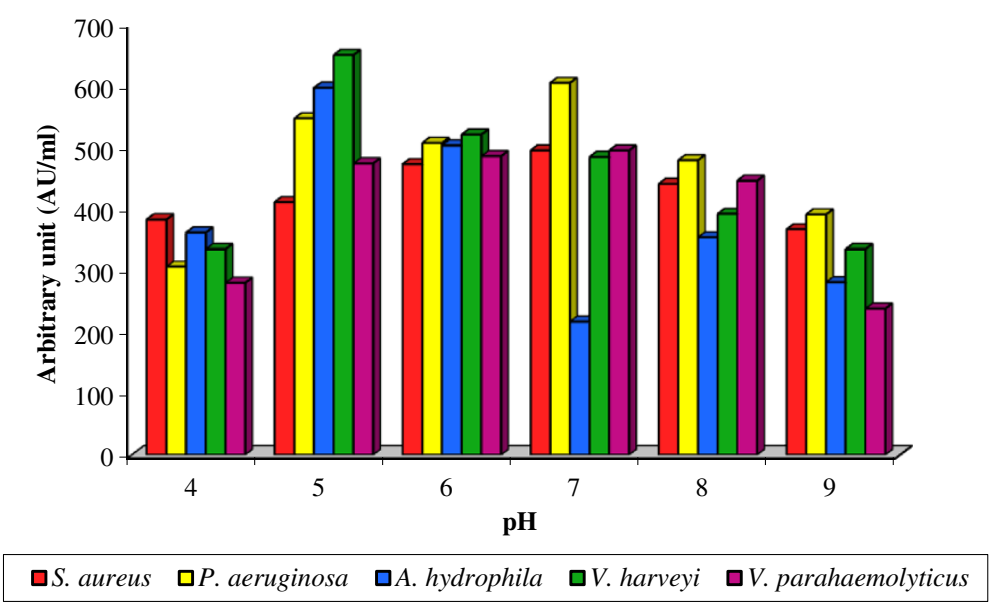

Figure 2 Effect of various $\mathrm{pH}$ on bacteriocin production by Lactobacillus sp. MSU3IR.

RZS C5 when cultured in MRS supplemented with lactose $(5 \% \mathrm{w} / \mathrm{v})$.

However the effect of nitrogen source on bacteriocin production by Lactobacillus sp. MSU3IR revealed that, ammonium acetate favored the maximum bacteriocin production $(354.4 \pm 2.65$ to $592.0 \pm 4.37 \mathrm{AU} / \mathrm{ml})$ and the minimum bacteriocin production was noticed in sodium nitrate $(200.0 \pm 2.07$ to $406.4 \pm 3.35 \mathrm{AU} / \mathrm{ml})$ supplied medium over the control $(318.4 \pm 2.33$ to $364.0 \pm 3.14 \mathrm{AU} / \mathrm{ml})$ [Figure 5]. Bacteriocin production by the candidate bacterium was statistically significant for indicator strains $(\mathrm{F}: 1.626 ; \mathrm{P}<0.05)$ and nitrogen sources (F: 2.682; $\mathrm{P}<0.05)$. Cell growth and bacteriocin production was shown to be influenced by organic nitrogen source [50]. Accordingly, the present result evidenced that the increment in bacteriocin production was attributed with inorganic nitrogen source.

The maximum $(408.0 \pm 3.15$ to $614.4 \pm 5.00 \mathrm{AU} / \mathrm{ml})$ bacteriocin production by Lactobacillus sp. MSU3IR was achieved with $3 \% \mathrm{NaCl}$ supplementation. However, at $6 \%$ $\mathrm{NaCl}$ concentration no bioactivity was detected over the control $(348.0 \pm 2.69$ to $414.4 \pm 4.25 \mathrm{AU} / \mathrm{ml})$ [Figure 6] . Bacteriocin production due to indicator strains (F: 1.863; $\mathrm{P}<0.05)$ and $\mathrm{NaCl}$ concentrations $(\mathrm{F}: 39.543 ; \mathrm{P}<0.001)$ was statistically significant. $\mathrm{NaCl}$ could alter the osmolarity of the cell membrane of bacterium which favored the more extrusion of bacteriocin from cell to media. In correlation, Herranz et al. [51] also reported that bacteriocin production by $E$. faceium $\mathrm{P} 13$ was high at $3 \% \mathrm{NaCl}$ and more than $7 \%$ of $\mathrm{NaCl}$ supplementation reciprocally affected the bacteriocin production.

Bacteriocin production by candidate bacterium emphasized that, the higher bacteriocin yield of $405.2 \pm$ 3.97 to $1126.4 \pm 0.63 \mathrm{AU} / \mathrm{ml}$ was attained in the medium supplied with Tween 80 compared to other tested surfactants. Incorporation of poly ethylene glycol (PEG) in culture medium was found to terminate the bacteriocin

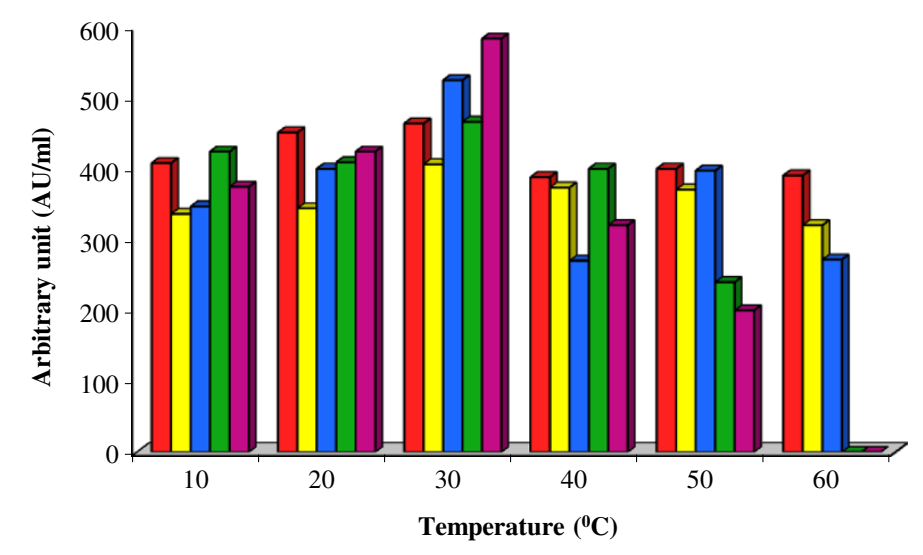

$\square S$. aureus $\square$ P. aeruginosa $\square$ A.hydrophila $\square$ V.harveyi $\square$ V.parahaemolyticus

Figure 3 Effect of various temperature on bacteriocin production by Lactobacillus sp. MSU3IR. 


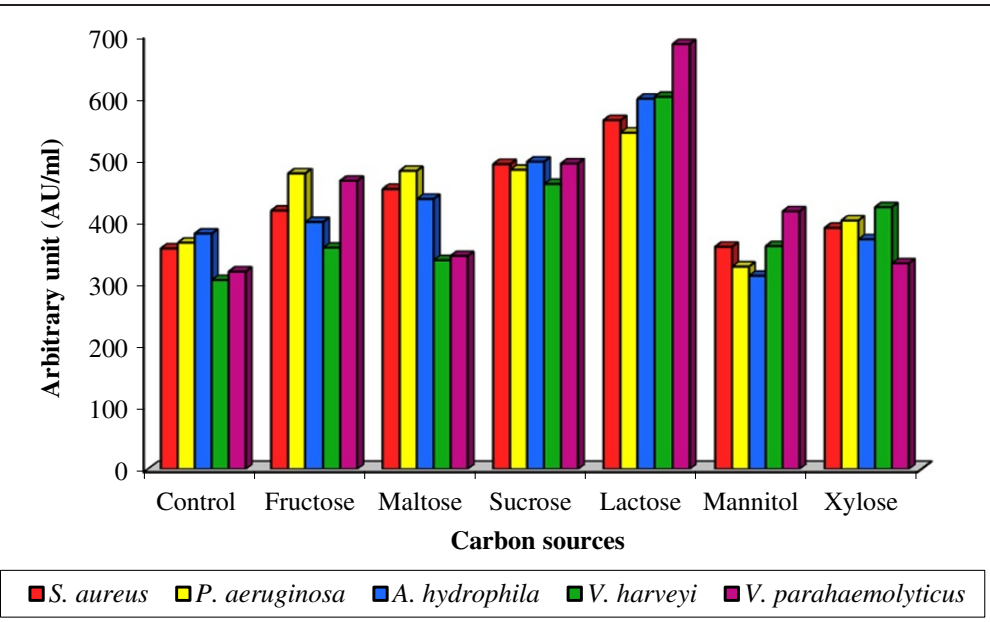

Figure 4 Effect of various carbon sources on bacteriocin production by Lactobacillus sp. MSU3IR.

production and expressed no bioactivity than the control $(302.4 \pm 0.26$ to $414.4 \pm 4.41 \mathrm{AU} / \mathrm{ml})$ [Figure 7]. Variation in bacteriocin production due to indicator strains (F: 1.043; $\mathrm{P}<0.05)$ and surfactants $(\mathrm{F}: 12.482 ; \mathrm{P}<0.001)$ was statistically significant. Similar results were recorded for plantaricin 428 [52], pediocin Actt [53], Lactacin B [54] and Lactocin 705 [38]. Possibly Tween 80 could change the surface tension of the producer cell thereby increasing the rate of bacteriocin release from the cell surface [52].

To ensure the maximum bacteriocin production, Lactobacillus sp. MSU3IR was cultured in various media. The maximum bacteriocin production $(393.2 \pm 2.61$ to $556.0 \pm$ $5.34 \mathrm{AU} / \mathrm{ml}$ ) was recorded in the control (MRS medium) and followed by Lactobacillus selection broth favoured the bacteriocin production $(341.2 \pm 2.36$ to $473.2 \pm 3.96$ $\mathrm{AU} / \mathrm{ml})$. However, the other production media resulted in minimal bacteriocin yield [Figure 8]. Bacteriocin yield due to indicator strains ( $\mathrm{F}: 6.439 ; \mathrm{P}<0.01)$ and various media (F: 10.676; $\mathrm{P}<0.001$ ) was statistically significant. Earlier reports also evidenced that MRS medium is a better medium for cell growth and bacteriocin production than the other culture media $[53,55,56]$.

\section{Partial purification of bacteriocin}

The baceriocin produced by Lactobacillus sp. MSU3IR was partially purified by dialysis and the molecular mass of the bacteriocin was determined by SDS-PAGE analysis. Results inferred that, the bacteriocin preparation contained two distinct bands weighing $39.26 \mathrm{kDa}$ and 6.38 $\mathrm{kDa}$ on comparison with the molecular mass of standard markers [Figure 9]. Supportively, the molecular mass of bacteriocin produced by lactic acid bacteria have been reported to fluctuate from $3.40-5.60 \mathrm{kDa}$ to $10.00-$ $45.00 \mathrm{kDa}[57]$.

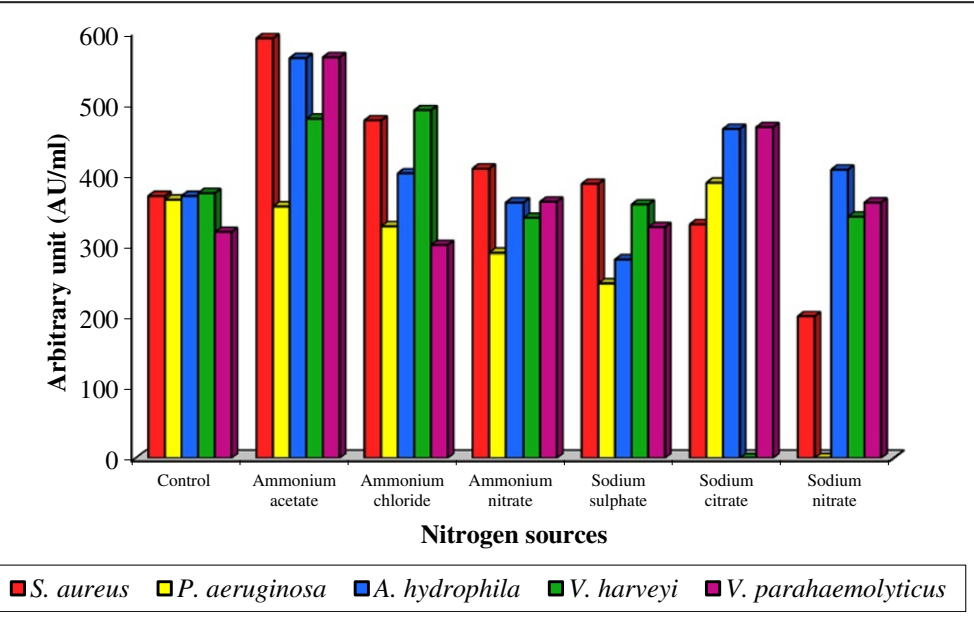

Figure 5 Effect of various nitrogen sources on bacteriocin production by Lactobacillus sp. MSU3IR. 


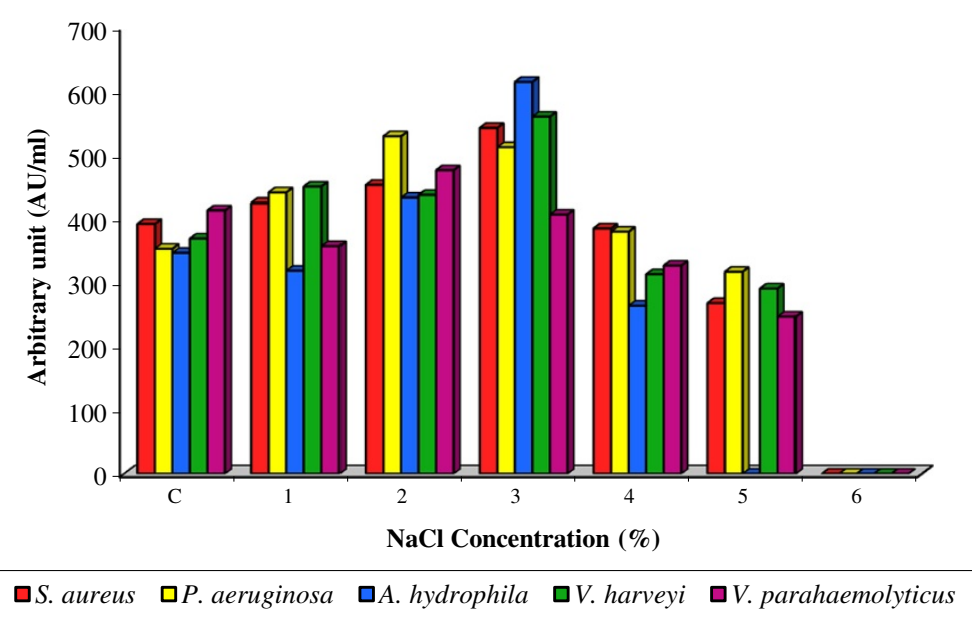

Figure 6 Effect of various $\mathrm{NaCl}$ concentrations on bacteriocin production by Lactobacillus sp. MSU3IR.

\section{Conclusion}

Bacteriocin produced by the candidate bacterium, Lactobacillus sp. MSU3IR showed good antagonistic activity against the tested shrimp pathogens. Hence, ex situ application of bacteriocin and Lactobacillus sp. MSU3IR as probiont in shrimp culture systems are to be studied. The optimization data on bacteriocin production provides basic information for further research on the statistical optimization and industrial scale up process.

\section{Methods}

\section{Lactobacillus strains}

For the enumeration and isolation of Lactobacillus strains, $1 \mathrm{ml}$ of milk sample was taken and serially diluted $\left(10^{-1}\right.$ to $10^{-5}$ ). From each dilution, $1 \mathrm{ml}$ of sample was taken and pour plated on Man Rogosa Sharpe (MRS) agar plates. After this, the plates were incubated at $37^{\circ} \mathrm{C}$ for $48 \mathrm{~h}$ and the total number of individual viable colonies was counted using a cubic colony counter. Then the morphologically identical colonies were isolated and identified as Lactobacillus sp. based on the physical and biochemical characteristics described by Holt et al. [58].

\section{Shrimp pathogens}

Indicator bacterial strains (shrimp pathogens) were collected from the microbial culture collections of Centre for Marine Science and Technology, Manonmaniam Sundaranar University, Kanyakumari District, Tamilnadu, India.

\section{Screening for bacteriocin production}

The isolated Lactobacillus strains were screened individually for bacteriocin production by the double layer method as described by Dopazo et al. [59]. For this, the isolated Lactobacillus strains were individually simple streaked on MRS agar plates and incubated at $37^{\circ} \mathrm{C}$ for $48 \mathrm{~h}$ which were overlaid using soft agar $(0.8 \%$ agar $)$ pre mixed with separate indicator stains. Then the plates

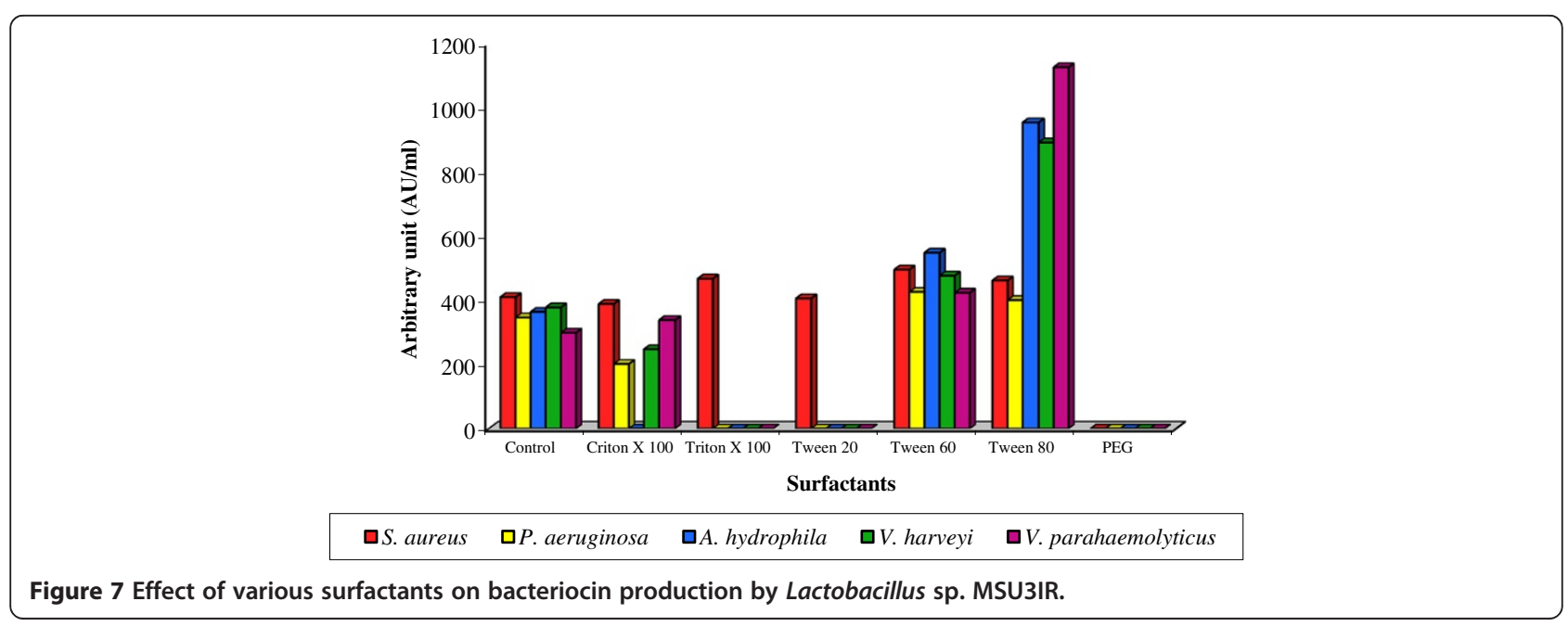




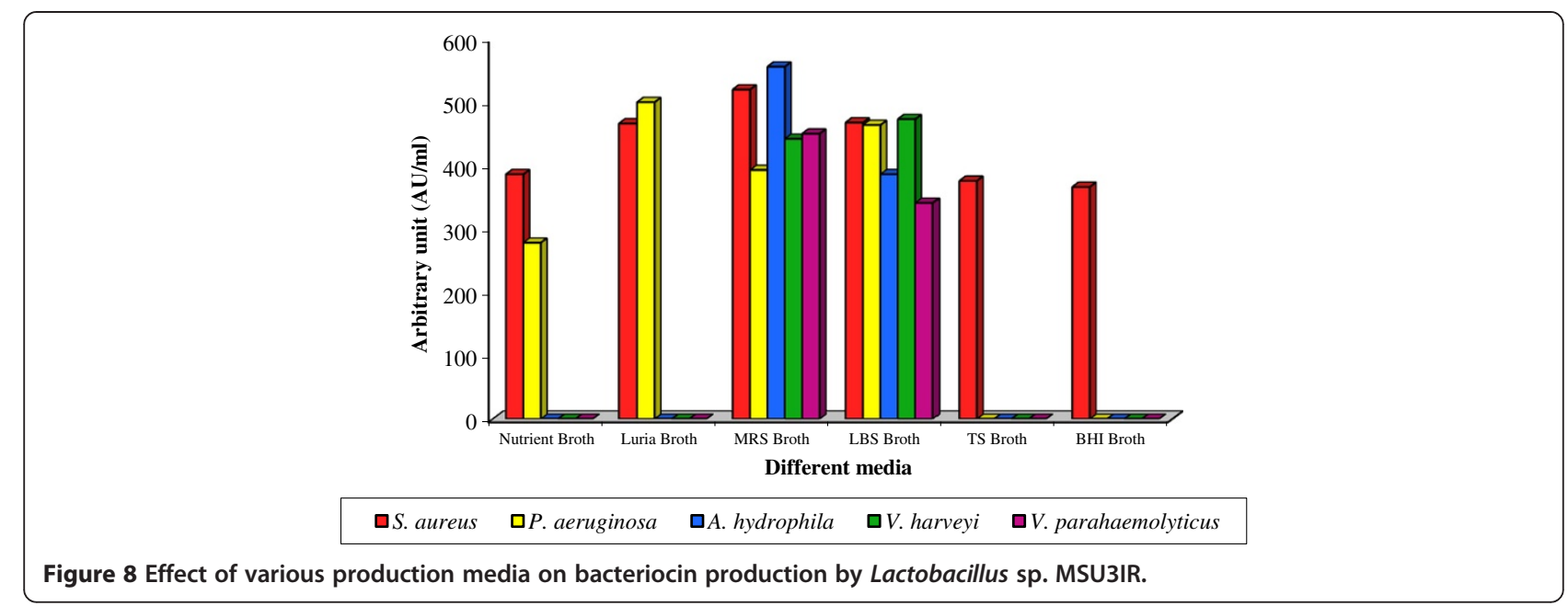

were incubated at $37^{\circ} \mathrm{C}$ for $24 \mathrm{~h}$. The Lactobacillus MSU3IR had better antagonistic activity against the indicator strains by forming clear zone of inhibition around it.

The potent strain Lactobacillus sp MSU3IR was selected for further study and was found to produce enhanced bacteriocin production in MRS broth at $30^{\circ} \mathrm{C}$ in $48 \mathrm{~h}$. Hence, the incubation parameters were maintained for analysis to use. The cells were then harvested by centrifugation at $4000 \times g$ for $30 \mathrm{~min}$ and the culture supernatant was subjected to membrane filtration $(0.22 \mu \mathrm{m})$.
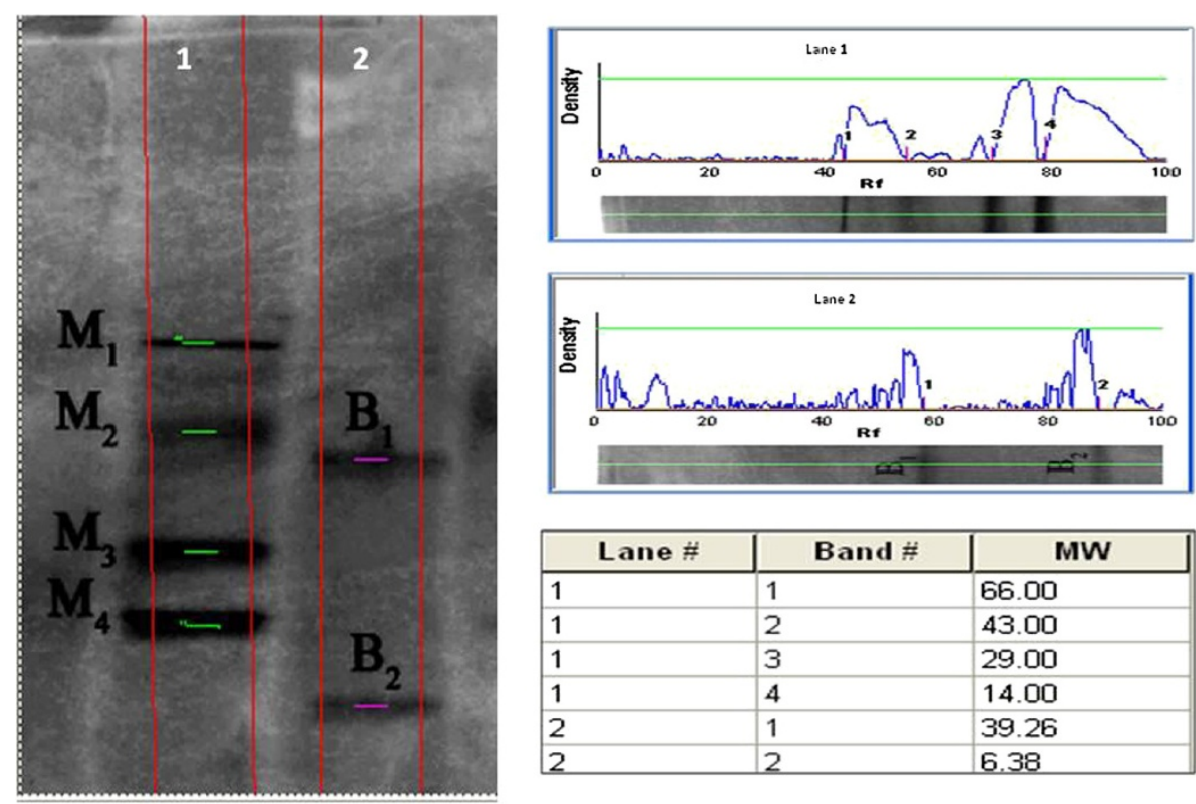

\begin{tabular}{|l|l|l|}
\hline \multicolumn{1}{|c|}{ Lane \# } & \multicolumn{1}{c|}{ Band $\#$} & \multicolumn{1}{c|}{ MW } \\
\hline 1 & 1 & 66.00 \\
\hline 1 & 2 & 43.00 \\
\hline 1 & 3 & 29.00 \\
\hline 1 & 4 & 14.00 \\
\hline 2 & 1 & 39.26 \\
\hline 2 & 2 & 6.38 \\
\hline
\end{tabular}

Lane 1: Molecular markers (KDa)

Lane 2: Bacteriocin bands

$\mathrm{M}_{1}$ : Marker 1 (66.00 KDa)

$\mathrm{M}_{2}$ : Marker 2 (43.00 KDa)

$M_{3}$ : Marker 3 (29.00 KDa)

$\mathrm{M}_{4}$ : Marker 4 (14.00 KDa)

$B_{1}$ : Band 1 (39.26 KDa)

$B_{2}$ : Band 2 (6.38 KDa)

Figure 9 Molecular mass determination of bacteriocin produced by Lactobacillus sp. MSU3IR on comparison with molecular markers in SDS-PAGE. 
Afterwards, the supernatant was neutralized using $3 \mathrm{~N}$ $\mathrm{NaOH}$. The resultant cell free neutralized supernatant (CFNS) was treated individually with enzymes, such as proteinase - K, $\alpha$ - chymotrypsin, trypsin and catalase (Sigma, India) at $\mathrm{pH} 7.0$ and temperature $37^{\circ} \mathrm{C}$ for $2 \mathrm{~h}$ in order to check whether the product is bacteriocin. The enzyme activity was terminated by heating the CFNS at $100^{\circ} \mathrm{C}$ for 10 min and then evaluated for bioactivity [60]. The potent candidate bacterium was characterized using the molecular tool, 16S rRNA sequencing.

\section{S rRNA sequencing}

The extraction of genomic DNA of the candidate strain was performed according to the method of Rainey et al. [61]. 16S rRNA gene was amplified using universal primers with the following PCR conditions. The DNA sequence was initially denatured for $5 \mathrm{~min}$ at $95^{\circ} \mathrm{C}$ and annealing of primer to the templates was achieved at $55^{\circ} \mathrm{C}$ for $30 \mathrm{Sec}$. Then the samples were maintained at $80^{\circ} \mathrm{C}$ to allow for hot start conditions and the addition of $5 \mu \mathrm{l}$ of enzyme solution containing $1 \mathrm{U}$ of Taq DNA polymerase in the $1 \times$ reaction buffer. PCR was performed with 40 thermal cycles under the standard high-stringency conditions. A 10 -min final extension at $72^{\circ} \mathrm{C}$ was performed at the end of the cycling steps, and then samples were maintained at $4^{\circ} \mathrm{C}$. The PCR product was sequenced using the genetic analyzer (Applied bio systems, USA). The comparison of $16 \mathrm{~S}$ rRNA gene sequence of the candidate strain and the $16 \mathrm{~S}$ rRNA sequences of other Lactobacillus species was done by using national center for biotechnology information - basic local alignment search tool (NCBI-BLAST) database, then the respective gene sequence of the candidate bacterium was deposited in NCBI and the accession number (JN561696) was obtained. The reference gene sequences were retrieved from NCBI GenBank database. All the sequences were aligned using the multiple sequence alignment program CLUSTAL-X 2.0.12 [62]. Phylogenetic tree was constructed using MEGA 4.0 program by following the method of Neighborhood Joining (NJ) described by Saitou and Nei [63].

\section{Agar well diffusion assay}

Bioactivity/production of the bacteriocin by the candidate bacterium was detected using agar well diffusion assay following the method of Tagg and McGiven [64]. In this assay, $25 \mu \mathrm{l}$ of CFNS was placed on each well of Muller Hinton agar plates which was previously overlaid with approximately $5 \mathrm{ml}$ soft agar (0.8\% agar). Soft agar was pre mixed individually with shrimp pathogens that were cultured for $24 \mathrm{~h}$. Then the plates were incubated at $37^{\circ} \mathrm{C}$ for $24 \mathrm{~h}$ and the antagonistic activity in arbitrary unit/ml (AU/ml) was calculated [65] as a measure of bacteriocin production.
$\mathrm{AU} / \mathrm{ml}=\frac{\text { Diameter of the zone of clearance }(\mathrm{mm}) \times 1000}{\text { Volume taken in the well }(\mu \mathrm{l})}$

\section{Composition of production medium}

The production medium used in this study is MRS medium and its composition ( $\mathrm{g} / \mathrm{l}$ ) is as follows: protease peptone: 10.0, beef extract: 1.0, yeast extract: 5.0 , dextrose: 20.0, polysorbate 80: 1.0, ammonium citrate: 20.0, sodium acetate: 5.0, magnesium sulphate: 0.1, manganese sulphate: 0.05 and dipottasium phosphate: 2.0 at a final $\mathrm{pH}$ of $6.5 \pm 0.20$.

\section{Optimization of culture conditions}

The influence of $\mathrm{pH}$ on bacteriocin production by the Lactobacillus sp. MSU3IR was examined. For this experimental $\mathrm{pH}$, such as 4.0, 5.0, 6.0, 7.0 (control), 8.0 and 9.0 were fixed using $1 \mathrm{~N} \mathrm{NaOH}$ and $1 \mathrm{~N} \mathrm{HCl}$ in the culture medium. Similarly, bacteriocin production with the candidate bacterium was optimized by varying the incubation temperature individually viz., 10, 20, 30 (control), 40, 50 and $60^{\circ} \mathrm{C}$. All the flasks were then aseptically inoculated with Lactobacillus sp. MSU3IR and kept in an orbital shaker $(120 \mathrm{rpm})$ for $48 \mathrm{~h}$. Afterwards, the CFNS was collected from each flask by centrifugation and membrane $(0.22 \mu \mathrm{m})$ filtration. The bacteriocin production in terms of antagonistic activity $(\mathrm{AU} / \mathrm{ml})$ was examined against different shrimp pathogens by agar well diffusion assay.

\section{Optimization of media components}

To achieve the maximum bacteriocin production by Lactobacillus sp. MSU3IR, the various media components like carbon sources (fructose, maltose, sucrose, lactose, mannitol and xylose individually at 1.0\%) and nitrogen sources (ammonium acetate, ammonium chloride, ammonium nitrate, sodium sulphate, sodium citrate and sodium nitrate individually at $1.0 \%$ ) were substituted in the production medium. Similarly, $\mathrm{NaCl}$ at 1.0, 2.0, 3.0, 4.0, 5.0 and $6.0 \%$ concentrations and surfactants (Criton X100, Triton X-100, Tween 20, Tween 60, Tween 80 and Poly Ethylene Glycol individually at 1.0\%) were supplemented in the production medium. Appropriate control (MRS medium) was also maintained. Then, all the flasks were inoculated aseptically with Lactobacillus sp. MSU3IR and kept in an orbital shaker $(120 \mathrm{rpm})$ at $30^{\circ} \mathrm{C}$ for $48 \mathrm{~h}$. After that the CFNS was collected from each flask and examined for bioactivity to determine the bacteriocin production over shrimp pathogens by agar well diffusion assay.

Likewise, to achieve the maximum bacteriocin production, the Lactobacillus sp. MSU3IR was inoculated individually in sterile production medium, such as Nutrient broth, Luria broth, Lactobacillus selection broth, Tryptic Soy broth, Brain-Heart infusion broth and MRS broth 
(control). Then the flasks were incubated at $30^{\circ} \mathrm{C}$ for $48 \mathrm{~h}$ in an orbital shaker (120 rpm). The CFNS was obtained by centrifugation and membrane filtration. Then, the biogenic activity as a measure of bacteriocin production was estimated against indicator strains.

\section{Partial purification of bacteriocin}

Bacteriocin produced by the candidate bacterial strain was purified by the scheme of Bogovic-Matijasic et al. [66]. The candidate bacterium strain was inoculated into the optimized medium and kept under optimum culture conditions. After that the culture was centrifuged at $4000 \times \mathrm{g}$ for $30 \mathrm{~min}$ at $4^{\circ} \mathrm{C}$. Then, the cell free supernatant was precipitated by using $80 \%$ ammonium sulphate and settled down by centrifugation at $7000 \times g$ for $20 \mathrm{~min}$ at $4^{\circ} \mathrm{C}$. The pellet containing bacteriocin was suspended in $3 \mathrm{ml}$ of 5 $\mathrm{mM}$ sodium phosphate buffer $(\mathrm{pH}$ 5.0) and dialyzed against the same buffer for $24 \mathrm{~h}$ at $4^{\circ} \mathrm{C}$. The retenate was again tested for antagonistic activity against indicator strains to ensure the bioactivity and stored $\left(-20^{\circ} \mathrm{C}\right)$ in a sterile container for further analysis. The molecular mass of the dialysed bacteriocin was estimated through SDS-PAGE [67] and gel documentation system (Syngene, UK).

\section{Statistical analysis}

All the experiments were done in six replicates and data obtained in the present study were subjected to statistical analysis, such as two way analysis of variance (ANOVA) using SPSS 16.0 to determine the significant variations between the test groups.

\section{Abbreviations \\ LAB: Lactic Acid Bacteria; CFU: Colony-Forming Unit; CFNS: Cell Free Neutralized Supernatant; PEG: Poly Ethylene Glycol; MRS: Man Rogosa Sharpe; NCBI-BLAST: National Center for Biotechnology Information - Basic Local Alignment Search Tool; SDS-PAGE: Sodium Dodecyl Sulfate- Poly Acrylamide Gel Electrophoresis..}

\section{Competing interests}

The authors declare that they have no competing interests.

\section{Authors' contributions}

All authors have participated in the research and article preparation. All authors have approved the final article.

\section{Author details}

${ }^{1}$ CAS in Marine Biology, Faculty of Marine Sciences, Annamalai University, Parangipettai - 608 502, Tamilnadu, India. ${ }^{2}$ Centre for Marine Science and Technology, Manonmaniam Sundaranar University, Rajakkamangalam - 629 502 Kanyakumari District, Tamil Nadu, India. ${ }^{3}$ Directorate of Research, SRM University, Kattankulathur - 603203 Kanchipuram District, Tamilnadu, India. ${ }^{4}$ Centre for Ocean Research, Sathiyabama University, Chennai, Tamilnadu, India.

Received: 27 May 2012 Accepted: 3 May 2013

Published: 1 June 2013

\section{References}

1. Dehadrai PV: Aquaculture. New Delhi, India: A.D., Oxford and IBH publishing Co. Pvt. Ltd; 1992
2. Pass DA, Dybadahl R, Manion MM: Investigations into the causes of mortality in the pearl oyster Pinctata maxima (Jamson), in western Australia. Aquaculture 1987, 65:149-169.

3. Alvarez JD, Austin B, Alvarez AM, Reyes H: Vibrio harveyi: a pathogen of penaeid shrimps and fish in Venezuela. J Fish Disease 1998, 21:313-316

4. Lavilla-Pitogo CR, Leaño EM, Paner MG: Mortalities of pond-cultured juvenile shrimp, Penaeus monodon, associated with dominance of luminescent vibrios in the rearing environment. Aquaculture 1998, 164:337-349.

5. Diggles BK, Moss GA, Carson J, Anderson CD: Luminous vibriosis in rock lobster Jasus verreauxi (Decapoda: Palinuridae) phyllosoma larvae associated with infection by Vibrio harveyi. Dis Aqut Org 2000, 43:127-137.

6. Karunasagar I, Pai R, Malahti GR, Karunasagar I: Mass mortality of Penaeus monodon larvae due to antibiotic resistant Vibrio harveyi infection. Aquaculture 1994, 128:203-209.

7. Zhang $\mathrm{XH}$, Austin B: Pathogenicity of Vibrio harveyi to salmonids. $J$ Fish Dis 2000, 23:93-102.

8. Muroga K: Viral and bacterial diseases of marine fish and shellfish in Japanese hatcheries. Aquaculture 2001, 202:23-44.

9. Nielsen ME, Hoi L, Schmidt AS, Qian D, Shimada T, Shen JY, Larsen JL: Is Aeromonas hydrophila the dominant motile Aeromonas species that causes disease outbreaks in aquaculture production in the Zhejiang Province of China? Dis Aquat Organ 2001, 46:23-29.

10. Park SC, Shimamura I, Fukunaga M, Mori K, Naki T: Isolation of bacteiophage specific to a fish pathogen Pseudomonas plecoglossida, as a candidate for disease control. Appl Environ Microbiol 2000, 66:1416-1422.

11. Iriano A, Austin B: Probiotics in aquaculture. J Fish Dis 2002, 25:633-642.

12. Ajitha $S$, Sridhar $M$, Sridhar N, Singh ISB, Carghese V: Probiotic effects of lactic acid bacteria against Vibrio alginolyticus in Penaeus

(Fenneropenaeus) Indicus (H. Milne Edwards). Asian Fish Sci 2004, 17:71-80.

13. Balcazar $\mathrm{J}$, de Blas I, Ruiz-Zarzuela I, Cunningham D, Vendrell D, Muzquiz JL: The role of probiotics in aquaculture. Vet Microbiol 2006, 114:173-186.

14. Medellin-Peña MJ, Wang H, Johnson R, Anand S, Griffiths MW: Probiotics affect virulence-related gene expression in Escherichia coli 0157:H7. Appl Environ Microbiol 2007, 73(13):4259-4267.

15. Ravi AV, Musthafa KS, Jegathammbal G, Kathiresan K, Pandian SK: Screening and evaluation of probiotics as a biocontrol agent against pathogenic Vibrios in marine aquaculture. Let App/ Microbiol 2007, 45:219-223.

16. Balcazar $\mathrm{L}$, Rojas-Luna T, Cunningham DP: Effect of the addition of four potential probiotic strains on the survival of pacific white shrimp (Litopenaeus vannamei) following immersion challenge with Vibrio parahaemolyticus. J Inverte Pathol 2007, 96:147-150.

17. Verschuere $L$, Rombaut $G$, Sorgeloos P, Verstraete $W$ : Probiotic bacteria as biological control agents in aquaculture. Microbiol Mol Biol Rev 2000, 64:655-671.

18. De Vrese D, Schrezenmeir M: A comprehensive review that critically evaluates modes of actions and medicinal applications of prebiotics and synbiotics. J. Adv Biochem Eng Biotechnol 2008, 111:1-66.

19. Renye JA, Somkuti GA, Paul M, Van Hekken DL: Characterization of antilisterial bacteriocins produced by Enterococcus faecium and Enterococcus durans isolates from Hispanic-style cheeses. J Ind Microbiol Biotech 2008, 36(2):261-268.

20. Lubelski J, Rink R, Khusainov R, Moll GN, Kuipers OP: Biosynthesis, immunity, regulation, mode of action and engineering of the model lantibiotic nisin. Cell Mol Life Sci 2008, 65:455-476.

21. Axelson LT: Lactic acid bacteria: classification and physiology. New York, USA: Salminen, Inc; 1993:1-63.

22. Tagg JR, Dajani AS, Wannamaker LW: Bacteriocins of gram-positive bacteria. Bacteriol Rev 1976, 40:722-756.

23. Klaenhammer TT: Genetics of bacteriocins produced by lactic acid bacteria. FEMS Microbiol Rev 1993, 12:39-86.

24. De Vuyst L, Vandamme EJ: Influence of the carbon source on nisin production in Lactococcus lactis subsp. Lactis batch fermentations. J Gen Microbiol 1992, 138:571-5786.

25. Parente $\mathrm{E}$, Ricciardi A, Addario G: Influence of $\mathrm{pH}$ on growth and bacteriocin production by Lactococcus lactis subsp. lactis 140NWC during batch fermentation. Appl Microbiol Biotechnol 1994, 41:388-394.

26. Møortvedt-Abildgaard Cl, Nissen-Meyer J, Jelle B, Grenov B, Skaugen M, Nes IF: Production and pH-dependent bactericidal activity of lactocin S, a lantibiotic from Lactobacillus sake L45. Appl Environ Microbiol 1995, $61: 175-179$ 
27. Leroy F, De Vuyst L: Temperature and $\mathrm{pH}$ conditions that prevail during fermentation of sausages are optimal for production of the antilisterial bacteriocin sakacin K. Appl Environ Microbiol 1999, 65:974-981.

28. Ganzle MG, Weber S, Hammes WP: Effect of ecological factors on the inhibitory spectrum and activity of bacteriocins. Int J Food Microbiol 1999, 46:207-217.

29. Keren T, Yarmus M, Halevy G, Shapira R: Immunodetection of the bacteriocin lacticin RM: analysis of the influence of temperature and Tween 80 on its expression and activity. Appl Environ Microbiol 2004, 70:2098-2104

30. Mataragas M, Drosinos EH, Tsakalidou E, Metaxopoulos E: Influence of nutrients on growth and bacteriocin production by Leuconostoc mesenteroides L124 and Lactobacillus curvatus L442. Antonie Van Leeuwenhoek 2004, 85:191-198.

31. Gatesoupe FJ: The use of probiotics in aquaculture. Aquaculture 1999, 180:147-165.

32. Holzapfel WH, Schillinger U: Introduction to probiotics. Food Res Int 2002, 35:109-116.

33. Hjelm M, Bergh O, Riaza A, Nielsen J, Melchiorsen J, Jensen S, Duncan H, Ahrens P, Birkbeck H, Gram L: Selection and identification of autochthonous potential probiotic bacteria from turbot larvae (Scophthalmus maximus) rearing units. Syst Appl Microbiol 2004, 27(3):360-371.

34. Stoffels $G$, Nes IF, Guomundsdottir A: Isolation and properties of a bacteriocin-producing Carnobacterium piscicola isolated from fish. J Appl Bacteriol 1992, 73:309-316.

35. Pilet MF, Dousset X, Barre R, Novel G, Dcsmazeaud M, Piard JC: Evidence for two bacteriocins produced by Carnobacterium piscicola and Carnobacterium divergens isolated from fish and active against Listeria monocytogene. J Food Prot 1995, 58:256-262.

36. Klaenhammer TR: Bacteriocins of lactic acid bacteria. Biochimie 1988, 70:337-349.

37. Lewus CB, Montville TJ: Detection of bacteriocins produced by lactic acid bacteria. J Microbiol Methods 1991, 13:145-150.

38. Vignolo GM, Kairuz MN, Ruiz-Holgado AAP, Oliver G: Influence of growth conditions on the production of lactocin 705, a bacteriocin produced by Lactobacillus casei CRL 705. J Appl Bacteriol 1995, 78:5-10.

39. Krier F, Revol-Junelles AM, Germain P: Influence of temperature and $\mathrm{pH}$ on production of two bacteriocins by Leuconostoc mesenteroides subsp. mesenteroides FR52 during batch fermentation. Appl Microbiol Biotechnol 1998, 50:359-363.

40. Chinachoti N, Matsusaki H, Sonomoto K, Ishikazi A: Utilization of xylose as an alternative carbon source for nisin $\mathrm{Z}$ production by Lactococcus lactis IO-1. J Fac Agric Kyushu Univ 1997, 42:171-181.

41. Matsusaki H, Endo N, Sonomoto K, Ishizaki A: Lantibiotic nisin Z fermentative production by Lactococcus lactis IO-1; relationship between production of the lantibiotic and lactate and cell growth. Appl Microbiol Biotechnol 1996, 45:36-40.

42. Parente E, Ricciardi A: Production, recovery and purification of bacteriocins from lactic acid bacteria. Appl Microbiol Biotech 1999, 52:628-638.

43. Zamfir M, Callewaert R, Cornea PC, De Vuyst L: Production kinetics of acidophilin 801, a bacteriocin pro-duced by Lactobacillus acidophilus IBB 801. FEMS Microbiol Lett 2000, 190:305-308.

44. Aasen IM, Moretro T, Katla T, Axelsson L, Storrø I: Influence of complex nutrients, temperature and $\mathrm{pH}$ on bacteriocin production by Lactobacillus sakei CCUG 42687. Appl Microbiol Biotechnol 2000, 53:159-166.

45. Barcena BJM, Sineriz F, Gonzalez De Llano D, Ro-driguez A, Sua'rez JE: Chemostat production of plantaricin C by Lactobacillus plantarum LL41. Appl Environ Microbiol 1998, 64:3512-3514

46. Yang $R$, Ray B: Factors influencing production of bacteriocins by lactic acid bacteria. Food Microbiol 1994, 11:281-291

47. Tahara T, Oshimura M, Umezawa C, Kanatani K: Isolation, partial characterization, and mode of action of acidocin J1132, a twocomponent bacteriocin produced by Lactobacillus acidophilus JCM 1132. Appl Environ Micro-biol 1996, 62:892-897.

48. Moonchai S, Madlhoo W, Jariyachavalit K, Shimizu H, Shioya S, Chauvatcharin S: Application of a mathematical model and dierential evolution algorithm approach to optimization of bacteriocin production by Lactococcus lactis C7. Bioproc Biosyst Eng 2005, 28:15-26.
49. Moreno MRF, Rea MC, Cogan TM, De Vuyst L: Applicability of a bacteriocin-producing Enterococcus faecium as a co-culture in Cheddar cheese manufac-ture. Int J Food Microbiol 2003, 81:73-84.

50. Kim WS, Hall RJ, Dunn NW: The effect of nisin concentration and nutrient depletion on nisin production of Lactococcus lactis. Appl Microbiol Biotechnol 1997, 48:449-453.

51. Herranz C, Martinez JM, Rodriguez JM, Hernandez PE, Cintas LM: Optimization of enterocin $\mathrm{P}$ production by batch fermentation of Enterococcus faecium P13 at constant pH. Appl Microbiol Biotech 2001, 56:378-383.

52. Verellen TL, Bruggeman G, Van Reenen CA, Dicks LMT, Vandamme EJ: Fermentation optimization of plantaricin 423 , a bacteriocin produced by Lactobacillus plantarum 423. J Ferment Bioeng 1998, 86:174-179.

53. Biswas SR, Ray P, Johnson MC, Ray B: Influence of growth conditions on the production of a bacteriocin, pediocin $\mathrm{AcH}$, by Pediococcus acidilatici H. App Envirn Microbiol 1991, 57:1265-1267.

54. Barefoot SF, Klaenhammer TR: Detection and activity of lactacin B, a bactericin produced by Lactobacillus acidophilus. Antimicrob Agents Chemother 1983, 26:328-334.

55. Ten Brink B, Minekus M, Van der Vossen JMBM, Leer RJ, Huis in't Veld JHJ: Antimicrobial activity of lactobacilli: preliminary characterization and optimization of production of acidocin $B$, a novel bacteriocin produced by Lactobacillus acidophilus M46. J Appl Bacteriol 1994, 77:140-148.

56. Toba T, Yoshioka E, Itoh T: Potential of Lactobacillus gasseri isolated from infant faeces to produce bacteriocin. Lett Appl Microbiol 1991, 12:228-231.

57. Moreno MRF, Leisner JJ, Tee LK, Radu S, Rusul G, Vancanneyt M, De Vuyst L: Microbial analysis of Malaysian tempeh, and characterization of two bacteriocins produced by isolates of Enterococcus faecium. J Applied Microbiol 2002, 92:147-157.

58. Holt JG, Krieg NR, Sneath PHA, Staley JT, Williams ST: Bergey's Manual of Determinative Bacteriology, Volume Ninth Edition. USA: Williams \& Wilkins; 1994.

59. Dopazo CP, Lemos ML, Lodeiros C, Bolinches J, Barja JL, Toranzo AE: Inhibitory activity of antibiotic producing marine bacteria against fish pathogens. J App/ Bacteriol 1988, 65:97-101.

60. Ralph WJ, Tagg JR, Ray B: Bacteriocin of gram positive bacteria. Microbiol Rev 1995, 59:171-200.

61. Rainey FA, Ward-Rainey N, Kroppenstedt RM, Stackebrandt E: The genus Nocardiopsis represents a phylogenetically coherent taxon and a distinct actinomycete lineage; proposal of Nocardiopsaceae fam. nov. Int J Syst Bacteriol 1996, 46:1088-1092

62. Thompson JD, Gibson TJ, Plewniak F, Jeanmougin F, Higgins DG: The ClustalX windows interface: flexible strategies for multiple sequence alignment aided by quality analysis tools. Nucleic Acid Res 1997, 24:4876-4882

63. Saitou N, Nei M: The neighbor-joining method: A new method for reconstructing phylogenetic trees. Mol Biol Evol 1987, 4:406-425.

64. Tagg JR, McGiven AR: Assay system for bacteriocins. App/ Microbio/ 1971, 21:943-944.

65. Bhaskar N, Sudeepa ES, Rashmi HN, Tamil Selvi A: Partial purification and characterization of protease of Bacillus proteolyticus CFR3001 isolated from fish processing waste and its antibacterial activities. Bioresour Technol 2007, 98:2758-2764.

66. Bogovic-Matijasic B, Rogelj I, Nes IF, Holo H: Isolation and characterisation of two bacteriocins of Lactobacillus acidophilus LF221. Appl Environ Microbiol 1998, 49:606-612.

67. Laemmli UK: Cleavage of structural proteins during the assembly of the head of bacteriophage T4. Nature 1970, 277:680-685.

doi:10.1186/2046-9063-9-12

Cite this article as: Iyapparaj et al:: Optimization of bacteriocin production by Lactobacillus sp. MSU3IR against shrimp bacterial pathogens. Aquatic Biosystems 2013 9:12. 